\title{
PAÍS EMERGENTE EM CIÊNCIA
}

Ano passado foram divulgados dados em diversas publicações mostrando o considerável aumento da produção científica no Brasil e seu peso na ciência global. Com isso, países que tradicionalmente mais contribuíam para a produção científica global perderam espaço para o Brasil e outros países. Passamos a ser considerado um país emergente na área científica e já somos responsáveis por $60 \%$ da produção científica da América Latina. Seguindo uma trajetória que já era ascendente, em 2007 o número de artigos em revistas indexadas alcançou a marca de 19.000 artigos e em 2010 subiu para 30.000. Atualmente o Brasil está na frente de diversos países tradicionais em pesquisa e na liderança do BRIC. Alguns pessimistas argumentam que esse aumento nos últimos anos foi devido à indexação de diversas revistas brasileira nas grandes bases científicas de dados, mas, em realidade, esse aumento foi oriundo de diversas políticas implementadas por órgãos de fomento nas esferas federal e estadual. A principal razão deste crescimento foi, sem dúvida, a quantidade e a regularidade dos investimentos realizados em P, D \& I. Só em 2009 se investiu 1,09\% do PIB, sendo que o setor privado foi responsável por $44 \%$ deste investimento. Não menos importantes foram os investimentos realizados por diversas FAPs, que há pouco tempo eram inoperantes ou investiam pouco em P, D \& I e bolsas, com exceção da FAPESP. Mais positivos foram os programas inovadores das agências federais de fomento e as diversas parcerias realizadas com as FAPs para concessão de bolsas e principalmente nas grandes redes cooperativas de pesquisa, como os INCTs e os PRONEX. O modelo cooperativo entre as agências de fomento agora está sendo reproduzido entre as próprias FAPs.

Outro aspecto positivo a ser ressaltado é a quantidade de doutores que estão sendo formados. Sem dúvida, o aumento da produção científica está relacionado com a formação destes jovens pesquisadores que estão sendo titulados a cada ano e, consequentemente, correlacionado com o aumento do número de programas de pós-graduação credenciado pela CAPES, em todas as áreas, assim como a qualificação dos mesmos.

As considerações elencadas acima indicam que estamos indo em uma direção correta e que aparentemente não temos problemas. Como estamos começando no país um novo ciclo de governo e já com inovações na governança, é de bom tom fazer algumas considerações que talvez não sejam tão otimistas como foi a parte inicial deste editorial.

Há notícias alvissareiras de que o novo governo prometeu chegar ao nível de investimento de 1,8\% em P, D \& I até 2014. Esperamos que essas notícias sejam confirmadas, mas esse valor ainda está muito aquém dos países desenvolvidos que investem entre 2,6-3,4\% do PIB, ou seja, quase o triplo do que se pretende chegar em 2014. Esse crescimento será no momento suficiente para manter o ambiente global competitivo e desenvolver as novas potencialidades. O mais importante é dar continuidade ao processo estabelecido no governo anterior e crescer. Qualquer retrocesso nos colocará novamente abaixo dos países "emergentes em ciência".

Uma das incógnitas nos investimentos em P, D \& I está na participação das indústrias brasileiras, principalmente as de médio porte, pois as grandes empresas, como a Petrobras, Braskem e Vale, já fazem isso como estratégia de sobrevivênvia em um mercado extremamente competitivo e onde os produtos e serviços inovadores lideram no mercado mundial. Nos países mais desenvolvidos o investimento em $\mathrm{P}, \mathrm{D}$ \& I pelas empresas é superior aos investimentos governamentais. Mesmo assim, vários editais e programas foram lançados pelas agências de fomento para estimular a interação entre os pesquisadores e o setor privado. No entanto, as notícias mais recentes indicam que as empresas inovaram, mas contratam menos pesquisadores. É fundamental que as empresas se dediquem às atividades de pesquisa, inovação e desenvolvimento e o setor governamental tem que continuar a estimulá-las com programas inovadores e de alto risco.

No Brasil a maior parte das pesquisas científicas é realizada nas universidades, mas elas precisam chegar à população. Não apenas como curiosidade, mas para aproximar ainda mais os jovens do conhecimento científico. O recente estudo divulgado pelo MCT sobre a "Percepção Pública da Ciência e Tecnologia" indicou que o número de interessados ou muito interessados em ciência subiu de 41 para $65 \%$. Isso sugere que, no futuro, a ciência poderá ser considerada como uma opção de carreira para os jovens antes de ingressarem nas universidades, mas para que isso ocorra é preciso melhorar a qualidade do ensino de ciências nos ciclos fundamental e secundário, tanto em infraestruturas como em laboratórios. Obviamente, tem-se que valorizar o trabalho dos professores com salários compatíveis e incentivar a continuidade de sua capacitação acadêmica. Outro aspecto preocupante e que deveria ser melhorado é o baixo índice de titulação de professores licenciados nas aréas centrais da ciência.

Em termos de formação de recursos humanos em nível de doutorado o desafio é triplicar o número de titulados, pois a ampliação dos recursos financeiros, das bolsas e o crescimento do PIB do país demandarão o envolvimento de mais pequisadores qualificados em ciência e tecnologia. A infraestrutura está sendo ampliada tanto em edificações como em equipamentos. Porém, um problem a ser enfretando com clareza e tranquilidade é o nível de muitas universidades que estão bem abaixo dos critérios de qualificação do corpo docente e envolvimento com a pesquisa, a fim de que possam ser credenciadas a permanecer com esse nome.

É orgulho para todos que o país tenha alcançado a $13^{\mathrm{a}}$ posição na produção científica mundial, principalmente, para aqueles pesquisadores que contribuíram para esse desempenho. Não obstante, é preciso que esse crescimento seja acompanhado com publicações seminais em revistas de alto índice de impacto e que esses artigos tenham citações que reflitam sua relevância. Esses pontos qualitativos ainda não foram alcançados. Também é importante que o impacto destas publicações esteja relacionado com a solução de problemas da população ou que se transformem em produtos tecnológicos. Os pesquisadores devem proteger o conhecimento desenvol- 
vido nos projetos através de patentes. Tal processo precisa ser incentivado e apoiado, pois em 2009 foram depositadas apenas 103 patentes no USPTO.

Alguns objetivos há longo tempo acalentados no imaginário dos cientistas estão sendo lentamente alcançados como, por exemplo, ter um fármaco genuinamente nacional. Como discutido em recente editorial do $\mathrm{JBCS}^{1}$ - "Como chegar aos fármacos verde-amarelos?" - já temos dois fármacos: o Acheflan (fitoterápico do Lab. Aché) e o Helleva ${ }^{\circledR}$ (lodenafila do Lab. Cristália). Estes dois exemplos demonstram que é possível ter um setor farmacêutico nacional forte e com fármacos inovadores. Ainda estão na pauta outros objetivos, como ter um Prêmio Nobel genuinamente brasileiro, ou seja, que o pesquisador tenha desenvolvido sua carreira científica no país. Isso não significa dizer que o país não tenha, ou tenha tido, cientistas com qualificação para receber este prêmio. Apenas para exemplificar citamos Carlos J. R. Chagas, Cesar M. G. Lattes e Johanna Döbereiner. Com certeza isso ocorrerá no tempo adequado, mas é importante se manter a elevação do nível de investimento a patamares similares aos países mais desenvolvidos, melhorar a infraestrutura das universidades e centros de pesquisa, bolsa para doutoramento com valores mais atrativos, manutenção do nível de financiamento para as redes cooperativas de pesquisa, atração de jovens pesquisadores para as fronteiras do conhecimento, dentre outras ações.

Além dos gargalos estruturais apontados ainda é possível piorar o quadro com leis bem intencionadas, mas equivocadamente executadas, como a legislação para evitar a biopirataria que engessou a pesquisa da biodiversidade e, se não for devidamente corrigida, inviabilizará a Química de Produtos Naturais no Brasil. Esse assunto já foi debatido pela Diretoria e Conselho da SBQ, que manifestaram sua preocupação a diversos órgãos governamentais quanto aos prejuízos causados pela aplicação desta legislação na formação e desenvolvimento dos grupos de pesquisa em produtos naturais. Hoje é mais fácil desmatar uma área, com licença dos órgãos ambientais, para plantio de soja e eucalipto ${ }^{2}$ do que se conseguir uma licença dos mesmos órgãos, em tempo cientificamente hábil, para pesquisar uma planta que poderá, ou não, resultar em novo conhecimento científico. Não é admissível que o pesquisador ou a universidade seja tratado como delinquente ou que se leve sete $\operatorname{anos}^{3}$ para se obter uma licença para coletar e pesquisar uma planta. Não se defende que não haja legislação ou controle sobre as atividades nos ecossistemas brasileiros, mas a vultosa multa aplicada à empresa Natura por biopirataria só traz desconforto, insegurança e desestímulo aos empreendedores e jovens pesquisadores que pretendem entrar nesta importante área da ciência. Esta política tal como está sendo executada favorece o prejuízo e a perda da oportunidade de se estudar, entender e aproveitar a nossa biodiversidade.

Como sempre afirmado pelo ex-Ministro Sergio Rezende nas suas conferências é preciso "tornar a política de C, T \& I uma política de estado".

\author{
Susana I. Córdoba de Torresi \\ Vera L. Pardini \\ Vitor F. Ferreira \\ Editores de QN
}

\section{REFERÊNCIAS}

1. Pinto, A. C.; Barreiro, E. J.; J. Braz. Chem. Soc. 2010, 21, 2173.

2. http://www.ecodebate.com.br/2010/06/14/a-suzano-e-o-espirito-dehumanidade-para-com-a-comunidade-de-santana-artigo-de-mayronregis/, acessada em Janeiro 2011.

3. Marques F.; Pesquisa FAPESP 2011, 179, 28. 